\title{
Arbitrating Consumer Claims under the Magnuson-Moss Warranty Act
}

Katie Wiechens $\dagger$

Suppose a consumer wants to buy a new mobile home. As part of the sale the manufacturer provides a written warranty, in which he promises to compensate the consumer if certain defects in the home arise within a specified time period. Suppose further that the warranty contains an arbitration clause. The clause requires the consumer to submit any claim arising under the warranty to binding arbitration. The consumer signs the agreement and purchases the home. Later, the consumer complains of defects in her new home, claiming that the warranty entitles her to compensation. The manufacturer objects to the consumer's claim. Is the consumer bound by her agreement to arbitrate the warranty claims, or may she disregard the agreement and pursue her claims in a judicial forum?

The answer to this question turns on the resolution of the conflict between two federal statutes: the Federal Arbitration Act ("FAA") and the Magnuson-Moss Warranty Act ("MMWA"). The FAA states that agreements to submit disputes to arbitration "shall be valid, irrevocable, and enforceable." Thus, if the FAA applies to the preceding scenario without qualification, the consumer must arbitrate her claims according to the agreement. The MMWA, on the other hand, regulates consumer warranties such as this one and specifically provides for certain "informal dispute settlement procedures." If the MMWA is understood to create an exception to the FAA's general mandate, the arbitration agreement is void, and the consumer is free to pursue her claim in a judicial forum.

Despite the FAA's all-encompassing language, the United States Supreme Court has held that it does not apply where "Congress intended to preclude a waiver of judicial remedies for the statutory, rights at issue." Under Shearson/American Express, Inc v McMahon,

B.A. 1998, Northwestern University; J.D. 2001, The University of Chicago.

Pub L No 68-401, 43 Stat 883 (1925), codified as amended at 9 USC $\$ 1$ et seq (1994).

Pub L No 93-637, 88 Stat 2183 (1975), codified at 15 USC $\S 2301$ et seq (1994).

9 USC $\$ 2$ (1994).

See, for example, Shearson/American Express, Inc v McMahon, 482 US 220, 226 (1987)

(stating that "[t]he Arbitration Act, standing alone, therefore mandates enforcement of agreements to arbitrate statutory claims").

515 USC $\$ 2310$ (a) (1994).

6 McMahon, 482 US at 227, citing Mitsubishi Motors Corp v Soler Chrysler-Plymouth, Inc, 
courts consider three factors to determine whether Congress intended to exclude a particular statutory claim from the FAA's mandate: (1) the text of the statute; (2) its legislative history; or (3) whether there is "an inherent conflict" between arbitration and the statute's underlying purposes.

The Supreme Court has not yet considered how the McMahon framework applies to the MMWA. In brief, the MMWA regulates the content of consumer warranties and allows a consumer to bring a civil action for breach of warranty.' Significantly, the MMWA also allows manufacturers to establish "informal dispute settlement procedures," which must be exhausted before a consumer can bring a claim in court. ${ }^{10}$ These dispute settlement procedures must meet certain minimum standards established by the Federal Trade Commission ("FTC")." The FTC, in turn, has promulgated regulations stating that binding arbitration agreements are not "informal dispute settlement procedure[s]," and are therefore disallowed under the MMWA."

The lower federal and state courts that have considered the issue are divided on whether the MMWA satisfies the requirements of McMahon and, therefore, creates an exception to the FAA. ${ }^{13}$ Applica-

473 US 614, 628 (1985) (noting that congressional intent regarding protection against waiver of the right to a judicial forum can be deduced from the text and legislative history).

7482 US 220 (1987) (holding respondents failed to meet burden of proof to show that Congress intended to preclude a waiver of the statutory rights in question, and thus respondents' Securities Exchange Act and RICO claims were arbitrable).

8 Id at 227, citing Mitsubishi Motors, 473 US at 628, 632-37 (finding the purpose of enforcing antitrust laws with treble damage claims does necessitate invalidating arbitration clause); Dean Witter Reynolds Inc v Byrd, 470 US 213, 218-21 (1985) (finding that arbitration of state law claims does not represent a conflict undermining congressional intent).

$9 \quad 15$ USC $\$ 2310(d)(1)$.

10 Id $\S 2310(a)(3)$.

11 Id $\S 2310$ (a)(2).

1216 CFR $\$ 700.8$ (2000) (noting that warrantors shall not indicate in any written warranty that the decision of any third party is final or binding); 16 CFR $\$ 703.5(\mathrm{j})$ (2000) (noting that decisions of the informal dispute settlement procedure are not legally binding on any person); Federal Trade Commission Rules, Regulations, Statements and Interpretations under Magnuson-Moss Warranty Act, 40 Fed Reg 60168, 60211 (1975) (noting that "reference within the written warranty to any binding, non-judicial remedy is prohibited by the Rule and the [Magnuson-Moss Warranty] Act"). See also Part II.B for a more detailed discussion of the FTC regulations.

13 Compare Pitchford v Oakwood Mobile Homes, Inc, 124 F Supp 2d 958, 962-65 (W D Va 2000 ) (holding that the arbitration agreement provision of a purchase contract was unenforceable under the MMWA's clear intent to encourage alternate dispute settlement procedures while not depriving any party of the right to have her warranty dispute heard in a judicial forum); Raesly $v$ Grand Housing, Inc, 105 F Supp 2d 562, 573 (S D Miss 2000) (holding that the MMWA forbids binding arbitration of a dispute arising from express written warranties); and Wilson v Waverlee Homes, Inc, 954 F Supp 1530, 1539 (M D Ala 1997), affd, 127 F3d 40 (11 th Cir 1997) (holding that the binding arbitration clauses contained in a sales contract are impermissible under the MMWA), with In re American Homestar of Lancaster, Inc, 50 SW3d 480, 490 (Tex 2001) (holding that nothing in MMWA's text, legislative history, or purposes precludes enforcement of arbitration agreements); Results Oriented, Inc v Crawford, 245 Ga App 432, 538 SE2d 
tion of McMahon to the MMWA's text, legislative history, and purposes alone is insufficient to evince congressional intent to bar arbitration of MMWA claims. ${ }^{14}$ Thus, the primary reason for the conflict among courts is disagreement about what role the FTC regulations should play in deciphering Congress's intent under McMahon. ${ }^{15}$ For example, some courts consider the FTC regulations as evidence of Congress's intent to exclude MMWA claims from the FAA's proarbitration mandate and hold that agreements to arbitrate MMWA claims are unenforceable. ${ }^{16}$ Meanwhile, other courts refuse to consider the FTC regulations when applying McMahon because they find the FTC's interpretation of the MMWA on the merits is flawed." All of these courts have upheld the arbitrability of MMWA claims. ${ }^{18}$ Neither courts nor commentators, however, have examined whether the regulations, even if a sound interpretation of the MMWA, are appropriate indicia of Congress's intent under the McMahon test.

This Comment proposes that courts should not consider the FTC regulations under McMahon at all. Specifically, this Comment argues that Congress did not delegate the power to exclude MMWA claims from arbitration when it enacted the MMWA. Rather, this Comment proposes that when an agency interpretation of a statute places that

73, 79-81 (2000) (holding that the MMWA does not preclude a manufacturer from arbitrating purchaser's express and implied warranty claims unless the purchaser could show that the arbitration clause was unconscionable), affd as Crawford v Results Oriented, Inc, $273 \mathrm{Ga} 884$ (2001); Southern Energy Homes, Inc v Ard, 772 S2d 1131, 1135 (Ala 2000) (holding the arbitration provisions of a written warranty binding and adopting Justice See's dissent in Southern Energy Homes, Inc v Lee, 732 S2d 994, 1004-13 (Ala 1999), thereby overruling the majority holding in Lee); and Southern Energy Homes, Inc v McCray, 2000 Ala LEXIS 524, *4-5 (holding that under the authority of $\mathrm{Ard}$, the MMWA did not invalidate arbitration clauses in a written warranty issued by a manufacturer of consumer goods).

14 This Comment argues that courts should exclude the FTC regulations from the $M c M a-$ hon test. A thorough application of the McMahon test once the regulations are excluded is beyond the scope of the Comment. Nevertheless, the conclusion that courts would uphold arbitration of MMWA claims under McMahon were it not for the regulations is justified by the Chevron USA Inc v Natural Resources Defense Council, Inc, 467 US 837 (1984), analysis in Part III.A.2. McMahon's three factors - text, legislative history, and purposes-are the same tools of statutory construction used in that Part to conclude that the regulations are not entitled to judicial deference under Chevron. Because under Chevron these three tools of construction prove that the MMWA cannot be understood to delegate to the FTC the authority to preclude arbitration, they prove also that the MMWA itself cannot be understood to preclude arbitration under McMahon.

15 See Part II.C.

16 See, for example, Pitchford, 124 F Supp 2d at 964-65; Raesly, 105 F Supp 2d at 573; Wilson, 954 F Supp at 1539.

17 See, for example, Ard, 772 S2d at 1135 (adopting Justice See's dissent in Lee, 732 S2d at 1011-12, in which Justice See found that the FTC regulations were not entitled to judicial deference under Chevron because the Supreme Court had rejected the FTC's rationale behind the ban on arbitration - as necessary to remedy inequality in bargaining power-in McMahon, 482 US at 230-32).

18 See, for example, Ard, 772 S2d at 1135 ; McCray, 2000 Ala LEXIS 524 at *4-5 (refusing to overturn $A r d$ ); Results Oriented, 538 SE2d at 81 (incorporating analysis from $A r d$ ). 
statute in direct conflict with the FAA, the agency's interpretation is not relevant under McMahon unless the agency is acting pursuant to an explicit delegation from Congress.

Part I provides an overview of the FAA and discusses application of the McMahon test. Part II describes the MMWA's key provisions and highlights the competing approaches lower federal and state courts have taken to resolve the tension between the two statutes. In particular, this Part discusses how these courts treat the FTC regulations when applying McMahon. Part III recommends that courts should not consider the FTC regulations when deciding whether Congress intended to prohibit binding arbitration of MMWA claims because the MMWA does not delegate to the FTC the decision to preclude arbitration of MMWA claims. Part III then analyzes the implications of excluding the FTC regulations from the McMahon inquiry.

\section{The FAA: A STRONG FEDERAL POLICY FAVORING ARBITRATION}

The FAA mandates that agreements to arbitrate "shall be valid, irrevocable, and enforceable, save upon such grounds as exist at law or in equity for the revocation of any contract." acts as a default rule, requiring enforcement of agreements to arbitrate any statutory claim absent contrary congressional command. The McMahon test is the tool that courts use to determine whether Congress has, in fact, overcome the default rule by creating an exception to the FAA's pro-arbitration presumption. ${ }^{20}$ This Part discusses the history of the FAA, the Supreme Court's adoption and application of McMahon, and the Court's treatment of agency interpretations under the McMahon framework.

\section{A. Overview of the FAA}

Congress enacted the FAA in $1925 .{ }^{21}$ Before that time, courts had consistently refused to enforce arbitration agreements, carefully guarding their dispute resolution function. ${ }^{22}$ The FAA attempted to reverse this long history of judicial hostility to arbitration by placing arbitration agreements "upon the same footing as other contracts.", Put simply, the FAA reflects the "congressional desire to enforce agreements into which parties [have] entered."

199 USC \& 2.

20 See Part I.B.

2143 Stat at 883-86.

22 See Joseph T. McLaughlin, Arbitrability: Current Trends in the United States, 59 Albany L Rev 905, 906 (1996) (noting the "long standing judicial hostility towards arbitration").

23 To Validate Certain Agreements for Arbitration, HR Rep No 96, 68th Cong, 1st Sess 1 (1924).

24 Dean Witter Reynolds Inc v Byrd, 470 US 213, 220 (1985). 
To this end, the FAA provides that agreements to submit disputes to arbitration "shall be valid, irrevocable, and enforceable, save upon such grounds as exist at law or in equity for the revocation of any contract.. ${ }^{25}$ That is, as long as an arbitration agreement is a valid contract under applicable state law, a trial court must refuse to hear claims subject to the agreement and must issue an order compelling the arbitration. ${ }^{26}$ Since its enactment in 1925, the FAA has successfully encouraged the enforcement of arbitration agreements. The Supreme Court has consistently interpreted the FAA as "a congressional declaration of a liberal federal policy favoring arbitration agreements.", Moreover, the Court has held that the FAA creates a strong presumption in favor of arbitration, stating "any doubts concerning the scope of arbitrable issues should be resolved in favor of arbitration."

\section{B. Defining the FAA's Limits: The McMahon Test}

Although the FAA embodies a strong federal policy favoring arbitration, its mandate is not absolute. The FAA does not apply where "Congress itself has evinced an intention to preclude a waiver of judicial remedies for the statutory rights at issue." ${ }^{, 29}$ Thus, the FAA acts as a default rule, requiring enforcement of arbitration agreements, except where Congress has specifically exempted a particular statutory claim from its application.

Courts consider three factors to determine whether Congress intended to prohibit agreements to arbitrate a particular statutory claim: (1) the text of the statute; (2) its legislative history; or (3) whether there is "an inherent conflict between arbitration and the statute's underlying purposes." "The burden is on the party opposing arbitration to demonstrate that Congress intended to preclude arbitration.

259 USC $\$ 2$.

269 USC $\$ 3$ (1994) (directing the court to stay the trial on application of one of the parties); 9 USC $\$ 4$ (1994) (requiring the court to direct the parties to arbitration).

27 Moses H. Cone Memorial Hospital v Mercury Construction Corp, 460 US 1, 24 (1983), citing 9 USC \& 2. See also Gilmer v Interstate/Johnson Lane Corp, 500 US 20, 26 (1991) (finding that while not all statutory claims may be appropriate for arbitration, a party who has agreed to arbitration should be held to the agreement unless Congress has shown an intent to preclude a waiver of judicial remedies for the statutory rights at issue); Perry $v$ Thomas, 482 US 483, 489 (1987) (noting that $\$ 2$ declares a liberal federal policy that favors arbitration agreements).

28 Moses H. Cone, 460 US at 24-25.

29 Mitsubishi Motors Corp v Soler Chrysler-Plymouth, Inc, 473 US 614, 628 (1985).

30 See McMahon, 482 US at 226 (explaining that "[ $t$ ]he Arbitration Act, standing alone ... mandates enforcement of agreements to arbitrate statutory claims").

31 Id at 227. In McMahon, the Supreme Court held that agreements to arbitrate Securities Exchange Act and civil RICO claims are enforceable under the FAA. Id at 238, 242. See Part I.C for a detailed discussion of McMahon's facts.

32 Id at 227 (noting that the party opposing arbitration has the burden to show that "Congress intended to preclude a waiver of judicial remedies for the statutory rights at issue"). 
While the Supreme Court has not yet applied McMahon to the MMWA, it has followed this three-part test in a number of other statutory contexts. In every statutory context it has considered, the Supreme Court has upheld application of the FAA. ${ }^{33}$ Specifically, the Court has held that the FAA requires enforcement of agreements to arbitrate claims arising under the Age Discrimination in Employment Act ("ADEA"), Sherman Act, ${ }^{35}$ Racketeer Influenced and Corrupt Organization Act, ${ }^{36}$ Securities Act of $1933,{ }^{37}$ Securities Exchange Act of $1934{ }^{38}$ and most recently, the Truth in Lending Act. ${ }^{39}$ In each of these cases, the Supreme Court concluded that the statute's text, legislative history, and purpose did not evince congressional intent to exclude the statute from application of the FAA. As detailed below, however, none of these cases has addressed the issue presented by the MMWA: how courts should treat agency interpretations of statutes under McMahon.

\section{The Supreme Court's Treatment of Agency Interpretations under McMahon}

The Supreme Court has never decided what role, if any, an agency's interpretation of a statute should have under the McMahon test. Perhaps the closest the Court has ever come to this issue was in McMahon itself, in which the Supreme Court held that the FAA required enforcement of agreements to arbitrate Securities Exchange Act claims. In reaching this result, the Court refused to consider an SEC regulation prohibiting arbitration of claims under the Securities Exchange Act. ${ }^{41}$ The Court found, and the SEC agreed, ${ }^{42}$ that the regu-

33 See notes 34-39 and accompanying text for cases upholding application of the FAA.

34 See Gilmer v Interstate/Johnson Lane Corp, 500 US 20, 35 (1991) (holding that claims arising under the ADEA are subject to binding arbitration under the FAA).

35 See Mitsubishi Motors, 473 US at 628-40 (holding that antitrust claims arising under the Sherman Act are arbitrable pursuant to the FAA).

36 See McMahon, 482 US at 242 (holding that agreements to arbitrate civil RICO claims are enforceable under the FAA).

37 See Rodriguez de Quijas v Shearson/American Express, Inc, 490 US 477, 484-86 (1989) (finding that parties must submit claims arising under the Securities Act to arbitration where they have agreed to do so), overruling Wilko v Swan, 346 US 427 (1953).

38 See McMahon, 482 US at 238 (holding that agreements to arbitrate Securities Exchange Act claims are enforceable under the FAA).

39 See Green Tree Financial Corp-Alabama v Randolph, 531 US 79, 88-92 (2000) (upholding an agreement to arbitrate a Truth in Lending Act claim under the FAA where respondent did not meet the burden of showing that arbitration would be prohibitively expensive). The FAA also requires enforcement of agreements to arbitrate state law claims. See Circuit City Stores, Inc v Adams, $121 \mathrm{~S} \mathrm{Ct} \mathrm{1302,} \mathrm{1311-12} \mathrm{(2001)} \mathrm{(upholding} \mathrm{agreement} \mathrm{to} \mathrm{arbitrate} \mathrm{claims}$ under California state tort law and California Fair Employment and Housing Act contained in plaintiff's employment contract).

$40 \quad 482$ US at 238

41 Id at $234 \mathrm{n} 3$. 
lation was not based on any independent analysis of the Act by the SEC but on court of appeals decisions. ${ }^{43}$ For that reason, the Court left open the question of how such a regulation should be treated under McMahon if based on an agency's independent interpretation of valid law.

The Court has also rejected the notion that mere agency involvement in the enforcement of a statute indicates Congress's intent to preclude arbitration. ${ }^{44}$ In Gilmer $v$ Interstate/Johnson Lane Corp, ${ }^{45}$ the Court held that ADEA claims are subject to the FAA, despite the Equal Employment Opportunity Commission's ("EEOC") active role in enforcing the ADEA. The Gilmer Court, however, did not face an EEOC regulation that prohibited arbitration and that placed the ADEA in direct conflict with the FAA. Thus, the Supreme Court has yet to resolve how courts applying the McMahon framework should treat an agency's independent determination that a statute prohibits arbitration.

\section{APPLYING MCMAHON: COMPETING APPROACHES TO RESOLVING THE CONFLICT BETWEEN THE FAA AND MMWA}

While the Supreme Court has not yet decided whether the MMWA creates an exception to the FAA, several lower federal and state courts have addressed the issue. ${ }^{47}$ Although all of these courts have generally adhered to the McMahon framework, they remain divided on the result. ${ }^{48}$ Disagreement about how to treat the FTC regulations prohibiting arbitration when applying McMahon is the primary reason for this division. ${ }^{49}$ This Part first examines the key provisions of the MMWA and the FTC regulations. It then describes competing approaches courts have taken to resolve the tension between the FAA and MMWA. In particular, it focuses on how these courts have treated the FTC regulations when applying McMahon.

\section{A. Consumer Protection and the MMWA}

In 1974, Congress passed the MMWA in response to a growing number of consumer complaints regarding the inadequacy of warran-

42 Id.

43 Id.

44 Gilmer $v$ Interstate/Johnson Lane Corp, 500 US 20, 28-29 (1991) (rejecting the mere involvement of an agency in enforcing a statute as sufficient to preclude arbitration).

45500 US 20 (1991).

46 Id at 28.

47 See note 13.

48 For a discussion of the disagreement between courts, see Part II.C.

49 See Part II.C. 
ties on consumer goods. ${ }^{\text {s0 }}$ The MMWA has three main purposes: "to improve the adequacy of information available to consumers, prevent deception, and improve competition in the marketing of consumer products." ${ }^{\text {"1 }}$ The MMWA is based on the premise that better-informed consumers will fuel a more competitive market for warranties, which will yield more generous warranties overall.

The MMWA employs a number of safeguards to advance these goals. First, the MMWA establishes minimum standards that warrantors must meet to feature a "full" warranty on a consumer product." Although the MMWA applies only to written warranties, ${ }^{54}$ and in fact does not require a manufacturer to offer a warranty at all, it nonetheless significantly limits a manufacturer's ability to disclaim implied warranties. ${ }^{55}$ In addition, the MMWA creates a federal cause of action for violation of the statute, stating that a consumer "may bring suit for damages and other legal and equitable relief" in any appropriate court.

Finally, the MMWA allows a manufacturer to incorporate "informal dispute settlement procedures" into a written warranty as long as the procedures comply with minimum standards prescribed by the FTC. ${ }^{57}$ If the manufacturer meets these requirements, the consumer must resort to the mechanism before she may bring a civil action. ${ }^{58}$ The MMWA does not, however, define what constitutes an "informal dispute settlement procedure," nor does it state that these informal procedures are the only forms of dispute resolution allowed under the statute. Rather, it provides only that such procedure is a precursor, not a bar, to litigation. ${ }^{59}$ Thus, the MMWA delegates to the FTC the authority to prescribe rules governing any procedure that falls within

so See Mace E. Gunter, Can Warrantors Make an End Run? The Magnuson-Moss Act and Mandatory Arbitration in Written Warranties, 34 Ga L Rev 1483, 1487-89 (2000) (discussing the general history of the MMWA).

$51 \quad 15$ USC \& 2302(a) (1994).

52 See Curtis R. Reitz, Consumer Product Warranties under Federal and State Laws 19-20 (ALI 2d ed 1987) (discussing the original purposes of the MMWA).

53 See 15 USC $\$ 2303$ (a) (noting that a warranty must meet the provisions of 15 USC $\S 2304$ to be considered a full warranty).

54 See Gunter, 34 Ga L Rev at 1491-92 (cited in note 50) (noting that Congress limited written warranties in order to stop sellers from drawing in consumers with a false sense of security in deceptive written warranties).

55 See 15 USC $\$ 2308$ (a) (listing situations when a supplier may not disclaim or modify implied warranties).

5615 USC $\$ 2310$ (d) (but placing limited restrictions, including minimum amount in controversy and class size).

5715 USC $\$ 2310(a)(2)$.

5815 USC $\$ 2310($ a)(3) (noting a "consumer may not commence a civil action ... unless he initially resorts to such procedures").

59 Id. 
the ambit of an "informal dispute settlement procedure" but does not define where those boundaries lie.

\section{B. FTC Regulations Prohibit Arbitration of MMWA Claims}

The FTC has promulgated several regulations establishing the requirements that "informal dispute settlement procedures" must meet in order to be valid under the MMWA. The FTC has adopted regulations stating that binding arbitration is not an "informal dispute settlement procedure," and, therefore, is disallowed under the MMWA. ${ }^{60}$ Specifically, the regulations provide that the "[d]ecisions of the [informal procedure] shall not be legally binding on any person." The FTC explains that this regulation prohibits warrantors from "requir[ing] consumers to resort to [informal procedures] whose decisions would be legally binding (e.g., binding arbitration)., ${ }^{62}$

The FTC goes beyond banning arbitration as part of any "informal dispute settlement procedures," however. The regulations also embody the agency's determination that the MMWA as a whole prohibits binding arbitration, stating that "reference within the written warranty to any binding, non-judicial remedy is prohibited by the Rule and the [Magnuson-Moss Warranty] Act." ${ }^{63}$ In this way, the FTC presumes that informal procedures are the only ones the MMWA permits. Thus, the FTC reasons that because the MMWA allows only informal procedures, and because arbitration is not such a procedure, the MMWA bans binding arbitration entirely.

\section{Competing Approaches to Resolving the FAA-MMWA Conflict}

The lower federal and state courts that have considered the tension between the FAA and MMWA are divided on the result. ${ }^{64}$ The courts disagree about how to treat the FTC regulations prohibiting binding arbitration under the McMahon test. Some courts, when applying McMahon, consider the FTC regulations as evidence of Congress's intent and conclude that agreements to arbitrate MMWA claims are unenforceable. ${ }^{65}$ These courts follow two main approaches when dealing with the regulations under McMahon. Some consider the regulations in addition to the three factors laid out in McMahon: the statute's text, legislative history, and purpose. ${ }^{66}$ Others consider

60 See 16 CFR $\S 703.5(j)$ ) 40 Fed Reg at 60211 (cited in note 12).

61 See 16 CFR $\$ 703.5(j)$ (emphasis added).

6240 Fed Reg at 60211 (cited in note 12).

63 Id (emphasis added).

64 See note 13.

65 See, for example, Pitchford v Oakwood Mobile Homes, Inc, 124 F Supp 2d 958, 963-65 (W D Va 2000); Wilson v Waverlee Homes, Inc, 954 F Supp 1530, 1538-39 (M D Ala 1997).

66 See, for example, Wilson, $954 \mathrm{~F}$ Supp at 1537-39 (basing its decision that the MMWA is 
only the regulations. ${ }^{67}$ In Wilson $v$ Waverlee Homes, ${ }^{68}$ for example, the district court followed the first approach and looked to the MMWA's text, legislative history, and purposes, in addition to the FTC regulations, as evidence of Congress's intent to bar arbitration. ${ }^{69}$ Therefore, the FTC regulations provided strong support for the court's conclusion that Congress intended to preclude binding arbitration of MMWA claims.

On the other hand, in Pitchford v Oakwood Mobile Homes, Inc, the district court followed the second approach and considered the FTC regulations alone as sufficient evidence of Congress's intent to prohibit arbitration under McMahon." Thus, the court did not examine the MMWA's text, legislative history, or purposes to determine congressional intent. ${ }^{\text {"I }}$ In this case, the FTC regulations clearly determined the outcome of the McMahon inquiry. Under either of these two approaches, a court's decision to rely on the regulations as evidence of Congress's intent invariably leads to the decision that the MMWA prohibits arbitration. ${ }^{73}$

Other courts refuse entirely to consider the FTC regulations under McMahon and uphold the arbitrability of MMWA claims. For example, in Southern Energy Homes, Inc $v$ Ard, ${ }^{74}$ the court applied McMahon and found that the MMWA's text, legislative history, and purposes were consistent with permitting arbitration. ${ }^{75}$ The court adopted the reasoning of the dissent in Southern. Energy Homes $v$ $\mathrm{Lee}^{76}$ which refused to consider the FTC regulations, concluding that the Supreme Court has specifically rejected the agency's reasoning behind its prohibition. ${ }^{n}$ Because the court rejected the regulations as

exempt from the FAA on the FTC regulations in addition to the MMWA's text, legislative history, and purposes).

67 See, for example, Pitchford, 124 F Supp 2d at 663-65 (finding that the MMWA's prohibition of arbitration and the MMWA's intent discernible from the FTC regulations themselves).

68954 F Supp 2d 1530 (M D Ala 1997).

69 Id at $1537-39$.

$70 \quad 124$ F Supp 2d 958 (W D Va 2000).

71 Id at $963-65$.

72 See id.

73 Interestingly, some of these courts specifically rely on Southern Energy Homes, Inc v Lee, 732 S2d 994 (Ala 1999), an Alabama Supreme Court case that was overruled by that court just one year later in Southern Energy Homes, Inc v Ard, 772 S2d 1131 (Ala 2000).

74772 S2d 1131 (Ala 2000).

75 Id at 1135 (overruling Lee and adopting the reasoning of Justice See's dissent in that case, id at 1008-13).

76732 S2d 994, 1008-13 (Ala 1999) (See dissenting).

77 See id at 1010-12. Specifically, Justice See found that the FTC's regulations were based on "mistrust" of arbitration that had explicitly been rejected by the Supreme Court in Gilmer, 500 US at 30 (stating that "[s]uch generalized attacks on arbitration 'rest on suspicion of arbitration ... [and are] far out of step with our current strong endorsement of the federal statutes favoring this method of resolving disputes"'), quoting Rodriguez de Quijas v Shearson/American Express, Inc, 490 US 477, 481 (1989). 
based on faulty reasoning, it did not reach the question whether such agency regulations, if otherwise valid interpretations of the MMWA, should be included in the McMahon inquiry.

\section{COURTS SHOULD NOT CONSIDER FTC REGULATIONS ProHibiting ARBITRATION AS EVIDENCE OF CONGRESS'S INTENT UNDER MCMAHON}

When applying McMahon, courts should not consider the FTC's prohibition of binding arbitration as evidence of Congress's intent to exclude MMWA claims from the purview of the FAA because the MMWA cannot reasonably be understood to give the FTC the power to override the FAA. That is, assuming that Congress could delegate to an administrative agency the power to decide whether a statute will be exempt from the FAA, Congress did not do so in the MMWA. This Comment proposes that when agency interpretation of a statute places that statute in direct conflict with the FAA, courts should consider the interpretation under McMahon only if the agency is acting pursuant to a specific delegation from Congress.

As discussed earlier, courts are divided on how to treat the FTC regulations when applying McMahon. ${ }^{79}$ Because nothing in the MMWA's text, legislative history, or purposes precludes arbitration, a court's decision of whether to consider the regulations effectively determines the conclusion the court will reach. ${ }^{\text {so }}$ Therefore, development of a consistent theory regarding treatment of agency regulations under McMahon would help achieve uniformity among courts facing this issue.

Part III.A discusses why courts should not interpret the MMWA as delegating to the FTC the decision to prohibit arbitration of MMWA claims. It argues that the FTC's total prohibition of arbitration is contrary to clear congressional intent expressed in the FAA and is not entitled to judicial deference under Chevron USA Inc $v$ Natural Resources Defense Council, Inc. ${ }^{81}$ Specifically, the MMWA's text, legislative history, and purposes neither expressly nor implicitly delegate to the FTC the power to override the FAA. As a result, the regulations are unlawful insofar as they bar arbitration of MMWA claims and should be vacated. Finally, this Part advocates interpreting the MMWA according to the presumptions favoring arbitration and

78 See $\mathrm{Ard}, 772 \mathrm{~S} 2 \mathrm{~d}$ at 1135 (failing to address the issue of an agency's valid interpretation); Lee, 732 S2d at 1008-13 (See dissenting) (same).

79 See note 13.

80 See Part II.C.

81467 US 837, 842-43 (1984) (noting that "[i]f the intent of Congress is clear, that is the end of the matter; for the court, as well as the agency, must give effect to the unambiguously expressed intent of Congress"). 
consistency in the law. Such an interpretation resolves interpretive doubts in favor of arbitration and nondelegation.

Part III.B examines the policy implications of excluding the FTC regulations, and other agency interpretations that conflict with the FAA, from the McMahon test absent a clear congressional delegation. This Part argues that requiring greater specificity from Congress when deciding to depart from the FAA yields several advantages, including the reduction of decision and error costs and increased political accountability. Finally, this Part rejects the arguments that this approach is unworkable and undermines the expertise of the FTC.

\section{A. The MMWA Does Not Grant the FTC the Power to Prohibit Binding Arbitration}

Courts should not consider the FTC regulations as evidence of Congress's intent under McMahon because the MMWA cannot reasonably be read to delegate to the FTC the authority to prohibit arbitration. First, the FTC's ban on arbitration is not entitled to judicial deference under Chevron because it is contrary to the congressional intent, expressed in the FAA, to uphold arbitration. ${ }^{82}$ Second, the MMWA does not change this result. Because the regulations directly conflict with the FAA, they can be consistent with congressional intent only if the MMWA creates an exception to the FAA. Both the MMWA itself and its interpretation according to presumptions favoring arbitration and continuity in the law demonstrate, however, that the MMWA does not create such an exception.

\section{The conflict between the FAA's pro-arbitration presumption and the FTC's regulations.}

An agency interpretation of a statute is entitled to judicial deference under Chevron if two conditions are met: (1) Congress has not directly spoken on the issue, and (2) the agency's interpretation is reasonable. ${ }^{83}$ In other words, the first prong of Chevron requires the court, as "the final authority on issues of statutory construction," to reject an agency regulation that is "contrary to clear congressional intent." ${ }^{84}$ To determine whether an interpretation is contrary to congressional intent, a court may look beyond the face of the particular statute at hand. ${ }^{85}$ A court can consider the statute's context and other

82 Id (noting that if congressional intent is clear, the court and agency must give effect to that intent).

83 Id at $842-44$.

84 Id at 843 n 9.

85 See FDA v Brown \& Williamson Tobacco Corp, 529 US 120, 132 (2000) (stating that "[i]n determining whether Congress has specifically addressed the question at issue, a reviewing court should not confine itself to examining a particular statutory provision in isolation"); $\mathrm{MCI}$ 
statutes as well." According to Justice Scalia, the more "that the meaning of a statute is apparent from its text and from its relationship with other laws," the less likely it is "that the triggering requirement for Chevron deference exists." ${ }^{, 87}$ When applying Chevron to the FTC regulations promulgated pursuant to the MMWA, a court may therefore consider whether the regulations are contrary to congressional intent expressed in the FAA.

By enacting the FAA, Congress clearly stated that all arbitration agreements "shall be valid, irrevocable, and enforceable," language that is unequivocal and allows exceptions only when Congress itself creates them. The FTC's regulations, meanwhile, prohibit arbitration in direct conflict with this command. Thus, unless the MMWA manifests a clear congressional desire to deviate from the FAA, the FTC regulations are contrary to the congressional intent expressed in the FAA and fail the first prong of Chevron. ${ }^{89}$ As the following three sections demonstrate, an interpretation of the MMWA in accordance with the presumptions in favor of arbitration and continuity in the law permits no room for regulations prohibiting arbitration.

\section{The MMWA's text, legislative history, and purposes.}

To find that the regulations are not contrary to congressional intent as expressed in the FAA, the MMWA must somehow authorize the agency to prohibit arbitration and override the FAA's mandate. Under Chevron, courts may "employ[] traditional tools of statutory construction" to determine whether such an authorization exists. ${ }^{90} \mathrm{~A}$ statute's text, legislative history, and purposes are three such fundamental tools of construction. ${ }^{91}$ Because nothing in the MMWA's text,

Telecommunications Corp v American Telephone \& Telegraph Co, 512 US 218, 226 (1994) (looking to "contextual indications" to determine whether agency interpretation is entitled to deference under Chevron).

86 See Brown v Gardner, 513 US 115, 118 (1994) (declaring an agency's interpretation of the word "injury" incorrect after examining the context of the language and similar language in other statutes); Brown \& Williamson, 529 US at 133 (stating that "the meaning of one statute may be affected by other Acts").

87 Antonin Scalia, Judicial Deference to Administrative Interpretations of Law, 1989 Duke L J 511, 521.

889 USC $\$ 2$.

89 See Chevron, 467 US at $842-43$ (noting the first prong focuses on the clarity of congressional intent). See, for example, McMahon, 482 US at 226-27 (stating that "[t]he [Federal] Arbitration Act, standing alone, therefore mandates enforcement of agreements to arbitrate statutory claims").

90467 US at $843 \mathrm{n} 9$.

91 See, for example, Estate of Cowart v Nicklos Drilling Co, 505 US 469, 476, 482 (1992) (relying on the plain meaning and purposes of Longshore and Harbor Workers' Compensation Act $\S 33$ in rejecting the agency's definition of "person entitled to compensation" under the Act); Dole v United Steelworkers of America, 494 US 26, 35-43 (1990) (holding that the text, structure, legislative history, and purposes of the Paperwork Reduction Act overrode the Office 
legislative history, or purposes can be understood to authorize the FTC to override the FAA by banning arbitration, the FTC regulations are not entitled to judicial deference under Chevron, are invalid, and should be excluded from the McMahon inquiry."

a) Text. The MMWA's text contains neither an express nor an implied delegation to the FTC to ban arbitration. Textual sources are the focal point of statutory interpretation, ${ }^{93}$ in which courts consider the statute's "plain meaning,", its structure as a whole, the similarity of language used elsewhere in the statute, the rules of grammar and syntax, and the statute's relationship with other laws. Under this approach, statutory text should be dispositive in the absence of other sources to the contrary.

The text of the MMWA does not authorize the FTC to ban arbitration because (1) arbitration is not an "informal dispute resolution procedure" over which the FTC rightfully has discretion, and (2) the FTC does not have the authority to declare informal procedures the only ones allowed by the MMWA. First, the MMWA allows warrantors to establish informal dispute resolution procedures that a consumer must exhaust before filing a claim in court, ${ }^{96}$ and it grants the FTC the power to establish rules governing those procedures. ${ }^{97}$ The FTC's authority, however, encompasses only "informal dispute settlement procedures," ${ }^{, 98}$ and thus it is necessary to define that term to understand the limits of the congressional delegation. Although the MMWA does not define "informal dispute settlement procedures," it

of Management and Budget's interpretation of the Act).

92 Text, legislative history, and purposes are used here to show that there is no delegation entitled to judicial deference under Chevron. While the Chevron and McMahon schemes of statutory interpretation utilize the same tools of construction in this analysis, they are different in key respects. Most importantly, under McMahon, ambiguity is resolved in favor of arbitration. Under Chevron, however, ambiguity is decided in favor of the agency, and in this case, against arbitration. See Part III.B.1 for further discussion of this point.

93 See Estate of Cowart, 505 US at 475 (Kennedy) (stating that "[i]n a statutory construction case, the beginning point must be the language of the statute, and when a statute speaks with clarity to an issue judicial inquiry into the statute's meaning, in all but the most extraordinary circumstance, is finished").

94 See William N. Eskridge, Jr., Textualism, the Unknown Ideal?, 96 Mich L Rev 1509, 1512 (1998) (defining "plain meaning" of a statute as the interpretation that an ordinary reader would give to the statutory language).

95 For example, in Tennessee Valley Authority v Hill, 437 US 153, 184 n 29, 193-94 (1978), modified by 16 USC $\$ 1536(\mathrm{~h})$ (1994) (allowing projects injuring endangered species under limited circumstances), the Court held that the plain meaning of the Endangered Species Act prohibited completion of the Tellico Dam. Chief Justice Burger noted that "[w]hen confronted with a statute which is plain and unambiguous on its face, we ordinarily do not look to legislative history as a guide to its meaning." Id at 184 n 29. See also Estate of Cowart, 505 US at 476 (stating that "[ $t]$ he controlling principle in this case is the basic and unexceptional rule that courts must give effect to the clear meaning of statutes as written").

9615 USC $\$ 2310(a)(3)$.

97 Id $\$ 2310(a)(2)$.

98

Id. 
does state that any such procedure must be exhausted before a consumer files a claim in court. ${ }^{\text {9" }}$ Courts universally apply a "whole act rule" when interpreting statutory text, recognizing that "[a] word or clause that is ambiguous at first glance might be clarified if "the same terminology is used elsewhere in a context that makes its meaning clear." "100

In contrast, binding arbitration is generally understood to be a substitute for a judicial forum, not a prerequisite to it. ${ }^{101}$ Webster's New International Dictionary defines arbitration as "the hearing and determination of a cause between parties in controversy by a person or persons chosen by the parties, or appointed under statutory authority, instead of by a judicial tribunal provided by law."

Thus, binding arbitration is not an "informal dispute settlement procedure" within the meaning of the MMWA, but rather a formal, final adjudication that takes the place of the judicial decisionmaking process. ${ }^{103}$ Understanding "informal dispute settlement procedures" to exclude binding arbitration makes sense of this provision. Taken as a whole, then, the MMWA's use of the phrase "informal dispute settlement procedures" does not encompass binding arbitration. As a result, the agency's power to make rules regarding these informal procedures does not include the ability to ban binding arbitration completely.

Finally, the MMWA's provision for "informal dispute settlement procedures" does not imply the prohibition of other formal dispute resolution procedures, such as arbitration. ${ }^{104}$ In Gilmer, the Supreme Court held that the ADEA's allowance for "informal methods of conciliation, conference, and persuasion" did not preclude arbitration of ADEA claims. ${ }^{105}$ Rather, the Court found that the ADEA's provision

99 Id $\S 2310(a)(3)$.

100 William N. Eskridge, Jr., Philip P. Frickey, and Elizabeth Garrett, Legislation and Statutory Interpretation 263-65 (Foundation 2000), quoting United Savings Association of Texas v Timbers of Inwood Forest Associates, Inc, 484 US 365, 371 (1988).

101 See Webster's New International Dictionary of the English Language 138 (Merriam 2d ed 1956). See also Mitsubishi Motors Corp v Soler Chrysler-Plymouth, Inc, 473 US 614, 628 (1985) (stating that "[b]y agreeing to arbitrate a statutory claim, a party does not forgo the substantive rights afforded by the statute; it only submits to their resolution in an arbitral, rather than a judicial, forum").

102 Webster's New International Dictionary at 138 (cited in note 101) (emphasis added).

103 See Tom Arnold, A Vocabulary of ADR Procedures, in Arbitration, Mediation, and Other ADR Methods 11, 33 (ALI 1993) (defining "binding arbitration," in relevant part, as a "fairly formal case presentation as in a court trial though as often held in a conference room or the like as in a borrowed courtroom").

104 See, for example, Eskridge, Frickey, and Garrett, Legislation and Statutory Interpretation at 255-56 (cited in note 100) (discussing inclusio unius est exclusio alterius, or "the inclusion ... of one thing suggests the exclusion of all others" as an unreliable canon of statutory interpretation).

105500 US at 29 , quoting 29 USC $\S 626(b)(1988)$. 
for these dispute resolution mechanisms evinced Congress's "flexible approach to resolution of [ADEA] claims." held, is consistent with this flexible statutory scheme. On this account, the MMWA's express provision for "informal dispute settlement procedures" does not imply the prohibition of other dispute resolution procedures. Because the MMWA's language providing for "informal dispute settlement procedures" neither includes nor prohibits binding arbitration, the FTC acted outside of its jurisdiction when it banned arbitration under the MMWA entirely.

b) Legislative history. The MMWA's legislative history confirms that Congress did not authorize the FTC to exempt the statute from the purview of the FAA. The House of Representatives Report states that "[a]n adverse decision in any informal dispute settlement proceeding would not be a bar to a civil action on the warranty involved in the proceeding." ${ }^{107}$ This language supports the textual reading that the FTC can make any rule with respect to "informal dispute settlement procedures," including the preservation of a judicial forum. Because binding arbitration is not an "informal dispute settlement procedure," however, this history does not authorize the FTC to prohibit arbitration completely.

Furthermore, the Supreme Court has rejected much more persuasive legislative history as evidence of Congress's intent to create an exception to the FAA. In McMahon, the Court concluded that the legislative history of a 1975 amendment to the Securities Exchange Act did not indicate Congress's desire to prohibit arbitration. ${ }^{108}$ In that case, the Conference Report explicitly adopted the Supreme Court's then-valid decision in Wilko $v$ Swan, ${ }^{109}$ prohibiting arbitration of Securities Act claims. ${ }^{110}$ The Supreme Court later overruled Wilko and upheld agreements to arbitrate Securities Act claims. ${ }^{11}$ Despite the explicit adoption of the Wilko rule against arbitration, the McMahon Court concluded that the report's language was not clear enough to create an exception to the FAA. ${ }^{112}$ Instead, the Court stated that it could not see how Congress intended to bar arbitration under the Ex-

106 Gilmer, 500 US at 29.

- 107 Magnuson-Moss Warranty-Federal Trade Commission Improvement Act, HR Rep No 93-1107, 93d Cong, 2d Sess 41 (1974), reprinted in 1974 USCCAN 7702, 7723.

108482 US at 236-37.

109346 US 427 (1953).

110 The Conference Report for the amendment to the Securities Exchange Act states, "It was the clear understanding of the conferees that this amendment did not change existing law, as articulated in Wilko v. Swan ... concerning the effect of arbitration proceedings provisions." Securities Acts Amendments of 1975, HR Rep No 94-229, 94th Cong, 1st Sess 111 (1975), reprinted in 1975 USCCAN 321, 342, quoted in McMahon, 482 US at 236-37.

111 Rodriguez de Quijas v Shearson/American Express, Inc, 490 US 477, 485 (1989), overruling Wilko.

112 McMahon, 482 US at 237-38. 
change Act "without enacting into law any provision remotely addressing that subject."

In contrast, the MMWA's legislative history makes no explicit mention of arbitration. It refers only generally to conditions of "informal dispute settlement procedures." ${ }^{114}$ Surely if Congress's specific endorsement of an existing ban on arbitration is insufficient to exempt the Securities Exchange Act from application of the FAA, so too is the vague language contained in the MMWA's history. The MMWA's legislative history, then, supports the textual reading that Congress did not intend to grant the FTC the power to bar binding arbitration.

c) Purposes. Likewise, the purposes of the MMWA do not imply that Congress authorized the FTC to ban arbitration. The MMWA aims to "improve the adequacy of information available to consumers, prevent deception, and improve competition in the marketing of consumer products." ${ }^{115}$ These consumer protection goals are fully consistent with arbitration. In Green Tree Financial Corp-Alabama $v$ Randolph, ${ }^{116}$ the Court upheld the arbitrability of claims arising under the Truth in Lending Act ("TILA"), a consumer protection statute similar to the MMWA. ${ }^{117}$ The Court did not suggest that any aspect of TILA's objective of protecting and informing consumers indicated a congressional desire to deviate from the FAA. ${ }^{118}$ Rather, the Supreme Court stressed that "even claims arising under a statute designed to further important social policies may be arbitrated." repeatedly adhered to this rationale and upheld arbitration in a number of other areas of great social importance, including the enforcement of age discrimination, ${ }^{120}$ antitrust, ${ }^{121}$ and securities laws."

Nevertheless, the FTC asserts that arbitration conflicts with the MMWA's goals for two main reasons: (1) arbitration procedures are insufficient to protect consumers armed with unequal bargaining power; and (2) binding arbitration conflicts with the MMWA's provision for a judicial forum. ${ }^{123}$ The Supreme Court has resoundingly re-

113 Id at 237.

114 HR Rep No 93-1107 at 40-41, reprinted in 1974 USCCAN at 7723 (cited in note 107).

11515 USC $\$ 2302(a)$.

116531 US $79(2000)$.

117 Id at 88-92.

118 Id.

119 Id at 90.

120 See Gilmer, 500 US at 27-28 (upholding arbitration of ADEA claim).

121 See Mitsubishi Motors Corp v Soler Chrysler-Plymouth, Inc, 473 US 614, 626, 628 (1985) (upholding arbitration of Sherman Act claim).

122 See McMahon, 482 US at 232, 238 (upholding arbitration of Securities Exchange Act claim); Rodriguez de Quijas, 490 US at 483 (same).

123 See 40 Fed Reg at 60210 (cited in note 12) (stating that the FTC has prohibited binding arbitration of MMWA claims because the agency "is not now convinced that any guidelines 
jected both of these premises. First, in Gilmer, the Supreme Court held that inequality in bargaining power between an employer and his employee was insufficient to create a conflict between the ADEA and the FAA. ${ }^{124}$ The Court emphasized that attacks on the adequacy of arbitration "'rest on suspicion of arbitration as a method of weakening the protections afforded in the substantive law to would-be complainants,' and as such, they are 'far out of step with our current strong endorsement of the federal statutes favoring this method of resolving disputes." "125

Second, the FTC's contention that arbitration conflicts with the MMWA's provision of a judicial forum is at odds with wellestablished Supreme Court jurisprudence. In almost every FAA case that the Supreme Court has decided, the statute allegedly in conflict with the FAA contained a similar provision. ${ }^{126}$ Nonetheless, every time, the Supreme Court held that the general provision of a judicial forum was insufficient to imply an intention to preclude arbitration. In sum, the FTC's rationale behind its regulations is without merit and cannot, under current FAA jurisprudence, sanction its decision to ban arbitration.

The FTC regulations are therefore not entitled to judicial deference under Chevron because they are contrary to the clear congressional intent expressed in the FAA favoring arbitration. The MMWA's text, legislative history, and purposes neither expressly nor implicitly authorize the FTC to contravene the FAA's mandate and bar arbitration of MMWA claims. As the next two sections demonstrate, interpretation of the MMWA according to canons favoring arbitration and continuity in the law only reinforce this result.

\section{The FAA's strong presumption in favor of arbitration.}

Under Chevron, courts may "employ[] traditional tools of statutory construction" to determine whether Congress has spoken on a

which it set out could ensure sufficient protection for consumers"); 16 CFR $\$ 700.8$ (stating that binding arbitration clauses "are deceptive since section 110(d) of the [MMWA] gives state and federal courts jurisdiction over suits for breach of warranty and service contract").

124500 US at 32 (stating that "[m]ere inequality in bargaining power [ ] is not a sufficient reason to hold that arbitration agreements are never enforceable in the employment context").

125 Id at 30, quoting Rodriguez de Quijas, 490 US at 481. See also Green Tree Financial, 531 US at 89-90 (recognizing the Court's rejection of "generalized attacks on arbitration" that stem from suspicion of the substantive fairness of arbitration).

126 See, for example, Gilmer, 500 US at 29 (holding that ADEA claims are arbitrable even though Congress grants state and federal courts concurrent jurisdiction over these claims); Rodriguez de Quijas, 490 US at 482-83 (stating that agreements to arbitrate Securities Act claims are valid notwithstanding the Act's provision of a judicial forum for relief); McMahon, 482 US at 229 (noting that the Security Exchange Act's grant of jurisdiction to federal district courts did not imply a congressional desire to deviate from the FAA when arbitration is adequate to protect the substantive rights in issue). 
particular issue. ${ }^{127}$ Many canons of interpretation are designed to preserve well-established federal policies in the absence of a clear statement from Congress to the contrary. ${ }^{128}$ As an example, Professor Cass Sunstein notes:

[T]here is a general federal policy against anticompetitive practices, and agencies will not be permitted to seize on ambiguous statutory language so as to defeat that policy. If Congress wants to make an exception to the policy in favor of competition, it is certainly permitted to do so. But agencies may not do so without congressional instruction."

Sunstein notes that courts employ similar canons of interpretation to force congressional decisionmaking in other areas, such as taxation and Native American affairs. ${ }^{130}$

The FAA enjoys a similar interpretive presumption as a proarbitration canon, favoring its application except where specifically exempted. The Supreme Court has stated that the FAA creates a substantive presumption favoring arbitration, which courts must apply when determining whether another statute conflicts with the FAA. Similarly, Professors William N. Eskridge, Jr., Philip P. Frickey, and Elizabeth Garrett specifically recognize the "[r]ule favoring arbitration of federal statutory claims" as a statute-based canon of construction used by the Rehnquist Court."

Thus, the MMWA must be interpreted with the strong presumption favoring arbitration embodied in the FAA in mind. ${ }^{133}$ Congress enacted the MMWA against the backdrop of the FAA and a long history of enforcement of arbitration agreements. ${ }^{134}$ Yet, the MMWA

127467 US at $843 \mathrm{n} 9$.

128 Cass R. Sunstein, Nondelegation Canons, 67 U Chi L Rev 315, 334 (2000) (describing nondelegation canons that are "designed to implement perceived public policy, by, among other things, giving sense and rationality the benefit of the doubt and by requiring Congress itself to speak if it wants to compromise policy that is perceived as generally held").

129 Id.

$130 \mathrm{Id}$.

131 Moses H. Cone Memorial Hospital v Mercury Construction Corp, 460 US 1, 24-25 (1983):

The Arbitration Act establishes that, as a matter of federal law, any doubts concerning the scope of arbitrable issues should be resolved in favor of arbitration, whether the problem at hand is the construction of the contract language itself or an allegation of waiver, delay, or a like defense to arbitrability.

132 Eskridge, Frickey, and Garrett, Legislation and Statutory Interpretation at 382 (cited in note 100).

133 See id (recognizing the rule in favor of arbitration of federal statutory claims as a canon of construction used to interpret federal statutes).

134 See McLaughlin, 59 Albany L Rev at 907 (cited in note 22) (stating that "[t]he Court's decisions [over the last twenty years] represent a strong endorsement for arbitration as an alternative form of dispute resolution"). 
provides only that the FTC shall establish rules regarding "informal dispute settlement procedures." ${ }^{, 135}$ It makes no mention of arbitration. It is unlikely that Congress would have delegated authority to the FTC without more specific language. Therefore, the MMWA's language is insufficient to overcome the FAA's general mandate favoring arbitration. Thus, the FAA trumps the FTC regulations.

Significantly, this approach does not preclude Congress from ever delegating the decision to prohibit arbitration completely in the MMWA or any other statute. ${ }^{136}$ It merely requires Congress to provide a clear statement of its intention to delegate this decision. For example, if Congress provided that "the FTC shall decide whether the FAA will apply to claims under the MMWA," or a like statement, the delegation to the agency would be clear, and therefore, effective. The FTC's decision regarding the arbitrability of MMWA claims would then flow from a congressional delegation specific enough to overcome the FAA and would be relevant under McMahon.

\section{The presumption in favor of statutory continuity and harmony.}

Congress does not enact statutes on a blank slate. ${ }^{137}$ Rather, every law is a part of an elaborate legal system. Interpreting statutes, where possible, to be consistent with other statutes encourages harmony and coherence in this scheme. ${ }^{138}$ This approach to statutory interpretation also promotes predictability and stability in the law. ${ }^{139}$ In this way, it resembles the practice of relying on common law principles to fill gaps left by statutes. ${ }^{140}$ Allowing statutes, as well as judge-made law, to fill these gaps is a natural extension of the common law approach.

13515 USC $\$ 2310(a)(2)$.

136 See Sunstein, $67 \mathrm{U}$ Chi L Rev at 336 (cited in note 128) (" $[\mathrm{T}]$ he nondelegation canons are merely tools of construction, and [ ] they should not be taken to forbid Congress from delegating expressly if it chooses.").

137 See Norman J. Singer, 2B Statutes and Statutory Construction $\S 53.01$ at 229-30 (Clark Boardman Callaghan 5th ed 1992) ("Legislation never is written on a clean slate, nor is it ever read in isolation or applied in a vacuum.").

138 See id (stating that harmony and consistency are positive values in statutory interpretation because they reduce arbitrariness and encourage impartiality); Ronald Dworkin, Law's Empire 227 (Belknap 1986) (arguing that integrity in law requires horizontal consistency in current legal principles).

139 See William N. Eskridge, Jr., Dynamic Statutory Interpretation 239 (Harvard 1994) (arguing that a liberal theory of statutory interpretation - which considers the original intent of the statute, prior precedents interpreting the statute, and traditional norms-preserves predictability and stability in the law).

140 For a general discussion of the common law approach, see Singer, 2B Statutes and Statutory Construction $\S 50$ at 89-115 (cited in note 137) (noting how antecedent common law on the statute's subject may help guide the interpretation). 
Under this approach, Congress is assumed not to create discontinuities in the law without some clear statement to that effect. ${ }^{\text {14 }}$

In light of these principles, the MMWA is best interpreted consistently, rather than in conflict, with the FAA. To promote coherence in the law with respect to arbitration, courts should uphold the FAA except where Congress has clearly stated otherwise. As discussed above, the MMWA's phrase "informal dispute settlement procedure" can be read to exclude binding arbitration from the list of remedies over which the FTC has statutory authority. ${ }^{142}$ Interpreting the MMWA in this way avoids conflict with the FAA and ensures a coherent federal scheme consistent with the FAA's strong presumption favoring arbitration. ${ }^{143}$ In addition, this approach recognizes Congress's inability to legislate on every detail, filling the gaps left in the MMWA with the background rule Congress clearly provided in the FAA.

\section{B. Advantages of Requiring Greater Specificity from Congress When Delegating the Power to Deviate from the FAA}

Excluding the FTC regulations from the McMahon inquiry forces Congress to be more specific when delegating to an agency the power to create an exception to the FAA. Several advantages result, such as the reduction in decision and error costs for both courts and Congress $^{144}$ as well as increased political accountability and deliberation regarding the decision to deviate from the FAA. ${ }^{1.55}$ Furthermore, requiring Congress to be explicit when delegating the decision to bar arbitration is a workable solution and does not prevent reaping the benefits of an administrative agency's expertise."

\section{Reduced decision costs for Congress and courts.}

For Congress, the FAA represents a valuable default rule. That is, unless Congress specifies otherwise, the FAA requires enforcement of agreements to arbitrate statutory claims. ${ }^{147}$ In this way, the FAA decides any statutory gaps left by Congress in the way that Congress would most often decide them-in favor of arbitration. ${ }^{14}$ As a result,

141 See Eskridge, Frickey, and Garrett, Legislation and Statutory Interpretation at 377 (cited in note 100) (describing the rule of continuity, or the assumption "that Congress does not create discontinuities in legal rights and obligations without some clear statement").

142 See Part III.A.2.a.

143 See Moses H. Cone Memorial Hospital v Mercury Construction Corp, 460 US 1, 24-25 (1983) (noting the presumption in favor of arbitration).

144 See Parts III.B.1 and III.B.2.

145 See Part III.B.3.

146 See Part III.B.4.

147 See McMahon, 482 US at 226-27.

148 See Moses H. Cone Memorial Hospital v Mercury Construction Corp, 460 US 1, 24-25 (1983) (noting that "any doubts concerning the scope of arbitrable issues should be resolved in 
the FAA minimizes decision costs for both Congress and courts by enforcing the most frequently desired result whenever a particular statute is silent. ${ }^{14}$

If courts consider the FTC regulations as evidence of Congress's intent in the absence of a more specific delegation, they undermine the value of the FAA as a default rule. If courts allow agencies to circumvent the FAA so easily, Congress is likely to determine that the only way to curb administrative discretion is for Congress to refuse to delegate decisionmaking wherever the issue of arbitration may arise. As a result, Congress will have to enact more detailed legislation every time it wants to ensure that agencies cannot evade the FAA. In other words, if courts consider the FTC regulations under McMahon, Congress will be required to specify each time it makes an agency delegation whether the FAA does and does not apply to a particular statute, as opposed to only when it does not apply.

Congress enacted the FAA to express a strong policy favoring arbitration. ${ }^{151}$ As a result, for any given statute, it is much more likely than not that Congress intended the FAA to apply. Because the number of cases in which Congress intends to prohibit arbitration are much fewer than those in which it does not, ${ }^{152}$ a rule that requires Congress to specify only where it does not intend arbitration to apply greatly reduces decision costs. ${ }^{153}$ Of course, Congress could enact a specific rule reinstating arbitration if, and when, agencies get it wrong. Note that this choice between courts and Congress as correctors of agency misinterpretation is not as simple as it appears. First, requiring Congress to reinstate arbitration when mistakes are made misses the point of having a default rule in the first place. Second, if agencies know that they must act pursuant to a clear congressional delegation to deviate from the FAA, agencies will be less likely to do so. As a result, Congress will be required to correct agency misrepresentations less frequently.

favor of arbitration").

149 Decision costs are "the costs of finding out what the law is - a cost faced by courts, Congress, or agencies." Cass R. Sunstein, Must Formalism Be Defended Empirically?, 66 U Chi L Rev 636, 647 (1999).

150 See Sidney A. Shapiro and Robert L. Glicksman, Congress, the Supreme Court, and the Quiet Revolution in Administrative Law, 1988 Duke L J 819, 871 (arguing that if courts do not review agency interpretations adequately, Congress "may conclude that the only way to limit agency discretion is to abandon the discretionary model of delegated power").

151 See Moses H. Cone, 460 US at 24 (noting that the FAA "is a congressional declaration of a liberal federal policy favoring arbitration agreements").

152 Consider id.

153 Moreover, if agencies know that they may only act pursuant to a clear congressional delegation to deviate from the FAA, agencies too will reduce their decision costs because they will not have to waste resources in trying to determine whether the FAA applies. 
In addition, exclusion of the FTC regulations from McMahon reduces decision costs for courts. Specifically, exclusion of the regulations allows judges to avoid conducting a laborious Chevron test every time they evaluate an agency regulation that conflicts with the FAA. $^{1.4}$ When reviewing an agency interpretation under Chevron, courts must determine whether the interpretation is contrary to congressional intent and is reasonable. ${ }^{1.55}$ Courts may employ traditional canons of construction to reach these conclusions, but the process is necessarily arduous. ${ }^{156}$

Furthermore, consideration of agency regulations under $\mathrm{McMa}$ hon absent a clear congressional delegation creates an unwieldy twostep inquiry that is exacerbated by the tension between McMahon and Chevron. When a court faces the conflict between the FAA and another statute, the court must determine whether there is congressional intent to exclude a statute from the FAA under McMahon. When an agency interpretation prohibiting arbitration is injected into the analysis, however, the court must also determine, under Chevron, whether there was congressional intent to uphold application of the FAA. Under Chevron, ambiguity is resolved in favor of the agency (which in this case would be in opposition to arbitration), while under McMahon, ambiguity is resolved in favor of arbitration. Injecting Chevron into the mix therefore conflicts with McMahon by shifting the presumption from pro-arbitration to anti-arbitration. Requiring Congress to make an explicit delegation prevents ambiguity under Chevron, simplifies the Chevron analysis, and avoids conflict with McMahon's pro-arbitration assumption.

The situation can be avoided entirely by requiring Congress to state with specificity when it chooses to depart from the FAA. Assuming, as discussed above, that Congress will depart from the FAA relatively infrequently, it is far more efficient for Congress to override the default rule when it so desires than for courts to engage in a laborious inquiry of interpreting congressional intent from ambiguous language each time an agency tries to override the FAA. ${ }^{157}$ Meanwhile, where an agency is in fact acting pursuant to a clear delegation from Congress, the Chevron analysis essentially becomes a formality and imposes little cost upon the courts. ${ }^{158}$

154 See Part III.A.

155467 US at $842-43$.

156 See Parts III.A. 2 and III.A.3

157 See Sunstein, 67 U Chi L Rev at 338 (cited in note 128) (pointing out that decision costs are much lower for courts applying nondelegation canons of construction as opposed to constitutional nondelegation principles). According to Sunstein, nondelegation canons involve a judicial decision about subject matter, whereas constitutional nondelegation principles involve harder questions of degree.

158 See Chevron, 467 US at 865 (noting that "an agency to which Congress has delegated 


\section{Reduced error costs. ${ }^{159}$}

The FAA embodies a congressional policy favoring arbitration. ${ }^{160}$ Absent a specific delegation from Congress, courts and agencies may err in deciding whether to allow a prohibition on arbitration. Agencies, for example, may mistakenly believe that Congress empowered them to exclude a particular statutory claim from arbitration. Courts, meanwhile, may err in deciding to take the agency's decision to deviate from the FAA as evidence of Congress's intent to do so as well. If the court or the agency gets it wrong, then the federal policies favoring arbitration and freedom of contract are undermined.

Even if courts and agencies are fairly competent at resolving these issues, the FAA protects interests significant enough that they should not be constricted unless Congress has specifically said so." The FAA and many decades of Supreme Court jurisprudence are testaments to the importance of arbitration. As discussed in the next section, Congress is the appropriate institution to resolve issues of such great importance.

In some cases, these error costs might be insignificant because Congress could easily correct them by enacting subsequent legislation. Given the demands on Congress's time and the volume of federal regulation, however, Congress would probably be unable to detect and correct all mistaken prohibitions on arbitration. ${ }^{162}$ As one commentator explains, "the same cumbersome organization and timeconsuming process upon which the framers relied to constrain the legislative branch in itself establishing or amending policy hinders it from using those devices effectively or extensively to direct the policy making of its delegees." ${ }^{163}$ Furthermore, requiring Congress constantly to correct agency mistakes is inefficient when the FAA, as a default rule, would prevent these mistakes ex ante.

policymaking responsibilities may, within the limits of that delegation, properly rely upon the incumbent administration's views of wise policy to inform its judgments").

159 Error costs are "the cost[s] of erroneous judicial decisions." Richard A. Posner, Economic Analysis of Law 599-600 (Aspen 5th ed 1998).

160 See Moses H. Cone Memorial Hospital v Mercury Construction Corp, 460 US 1, 24 (1983) (recognizing that the FAA is "a congressional declaration of a liberal federal policy favoring arbitration agreements").

161 See Sunstein, 67 U Chi L Rev at 338 (cited in note 128) (noting that "the nondelegation canons have the salutary function of ensuring that certain important rights and interests will not be compromised unless Congress has expressly decided to compromise them").

162 Cynthia R. Farina, Statutory Interpretation and the Balance of Power in the Administrative State, 89 Colum L Rev 452, 509 (1989) (noting that substantive legislation to overturn agency policy does not often occur because of institutional obstacles).

163 Id. 


\section{Increased deliberation and political accountability.}

Requiring Congress to provide a specific delegation encourages political accountability. ${ }^{164}$ Congress is more democratically accountable than are administrative agencies, and it should not punt an issue of this importance to an agency without specifically recognizing what it is doing. ${ }^{165}$ Heads of administrative agencies are bureaucrats who are not elected..$^{166}$ Nevertheless, some commentators consider agencies almost as politically accountable as Congress because the public can blame elected officials for agency action. ${ }^{167}$ Under this view, the legislative and executive branches must exercise control over agencies for them to be seen as "political" entities responsive to the will of the people. Although Congress and the President can exercise some control over administrative agencies, the sheer volume and complexity of federal regulation inhibits effective checks by these branches. ${ }^{168}$ For this reason, it is important that if Congress desires to leave policies of great significance to agencies, Congress must at least remain accountable for the delegation if not for the policy decision itself. Decisions to depart from well-established principles, such as the federal policy favoring arbitration, should be traceable to the more politically accountable legislature. ${ }^{16}$

The need for democratic accountability is only heightened by the importance of the issue at stake. If Congress chooses to leave a significant decision to the discretion of an agency, it should expressly specify its intent to do so. Justice Scalia states that most statutory ambiguities exist not because Congress intended a particular result or meant to leave the decision to an agency, but because Congress did not think about the matter at all. ${ }^{170}$ To the extent that Scalia is right,

164 See David Schoenbrod, Power without Responsibility: How Congress Abuses the People through Delegation 84-94 (Yale 1993) (arguing that agency delegation allows Congress to take credit for successes while shifting blame for failures to agencies).

165 See Farina, 89 Colum L Rev at 499-511 (cited in note 162) (challenging the idea that agencies are politically accountable entities and noting that the executive branch serves as the primary source of supervision of agencies).

166 See id at 504 (noting that the President appoints major officers with the advice and consent of the Senate, and because the Senate rarely interferes, the President gains power through handpicking bureaucrats).

167 See Eskridge, Frickey, and Garrett, Legislation and Statutory Interpretation at 317 (cited in note 100) (noting that agencies are accountable not only to the executive, but also to the legislature, which approves their leaders, amends the statutes they enforce, and establishes their budgets).

168 Farina, 89 Colum L Rev at 508-10 (cited in note 162) (noting that while the President has greater control than Congress over agencies, the huge magnitude of regulation will resist comprehensive management even by the most formidable President).

169 See Sunstein, $67 \mathrm{U}$ Chi L Rev at 335 (cited in note 128) (noting that "the nondelegation canons are ... a species of judicial minimalism, indeed democracy-forcing minimalism, designed to ensure that judgments are made by the democratically preferable institution").

170 See Scalia, 1989 Duke L J at 517 (cited in note 87). 
administrative agencies that interpret statutory ambiguities as delegations are not really acting according to congressional delegations of authority, but rather are engaging in policymaking on their own initiative. ${ }^{171}$ This is especially troubling where the policy involved is an important one. It is almost impossible for Congress to think of everything when it drafts a statute. ${ }^{12}$ Moreover, as discussed above, the volume and complexity of the regulatory state and Congress's heavy workload makes it unlikely that Congress can catch and correct an agency action every time it thinks the agency went too far."

By requiring specificity from Congress to deviate from important policies, courts ensure that these decisions are made in the "democratically preferable institution." "174 Under this approach, it is Congress that makes the choice, even if the choice itself is to delegate. Requiring specificity helps erase the possibility that an agency will deviate from well-accepted policies, such as arbitration, without some evidence of deliberation from Congress.

\section{Feasibility.}

Congress can, and has, specifically exempted other statutes from the reach of the FAA. ${ }^{175}$ For example, the Administrative Dispute Resolution Act provides that "[a]n agency may not require any person to consent to arbitration." "176 Another, the Convention on the Settlement of Investment Disputes Act of 1966, simply states that "[ $t]$ he Federal Arbitration Act ... shall not apply to enforcement of awards rendered pursuant to the convention." ${ }^{\prime 17}$ It would not be overly burdensome to require Congress to be just as specific when delegating the decision to deviate from the FAA to an administrative agency.

Additionally, forcing Congress to be specific when it exempts a statute from the FAA does little to undermine the efficiencies of the administrative state, which lie primarily in allowing Congress to avoid

171 See Schoenbrod, Power without Responsibility at 16-19 (cited in note 164) (arguing that Congress should not be allowed to delegate lawmaking authority to agencies because agencies should not be allowed to make law).

172 See John F. Manning, Textualism as a Nondelegation Doctrine, 97 Colum L Rev 673, 699 (1997) (describing the textualist reliance on the authority of the executory institutions to fill in the details of laws because "'no statute can be entirely precise,' and [ ] the elaboration of statutory detail inevitably takes place outside the formal confines of bicameralism and presentment"), quoting Mistretta $v$ United States, 488 US 361, 415 (1989) (Scalia dissenting).

173 See Farina, 89 Colum L Rev at 508 (cited in note 162) (noting that the framers deliberately placed practical constraints on Congress and the unforeseen shift of a significant portion of lawmaking power from Congress to administrative agencies has resulted in an inability of Congress "effectively or extensively to direct the policy making of its delegees").

174 Sunstein, $67 \mathrm{U}$ Chi L Rev at 335 (cited in note 128).

175 See, for example, 5 USC $\$ 575$ (a)(3) (1994); 22 USC \$ 1650a (1994).

1765 USC $\$ 575(a)(3)$.

17722 USC $\$ 1650$ a. 
immersion in legislative details by delegating responsibilities to agencies with expertise in their respective fields. The decision to limit the FAA, and even the decision to let the agency decide whether to limit the FAA, however, is not a small detail. Rather, it is a determination to depart from a well-established "body of federal substantive law of arbitrability." ${ }^{, 178}$ Deviation from the FAA is an important decision and is one that Congress will not frequently make. Furthermore, by specifically prohibiting arbitration of other statutory claims, Congress has shown that it can be explicit about this issue. ${ }^{179}$ Finally, this approach impacts the FTC's discretion only slightly, ${ }^{180}$ for the FTC is free to regulate dispute resolution procedures under the MMWA in any way it wants, so long as it does not run afoul of the FAA. Therefore, requiring a specific statement from Congress when it chooses either to deviate from the FAA itself, or allow an agency to do the same, is a practical solution that does not undermine the benefit of efficiency sought by the administrative state.

\section{The legal nature of the FTC regulations.}

A final reason for excluding the FTC regulations from the McMahon inquiry is the legal nature of the regulations themselves. In Chevron, the Supreme Court held that courts must defer to an agency's legal interpretation of the statute it administers as long as the interpretation is consistent with congressional intent and is reasonable. ${ }^{181}$ The FTC regulations present legal conclusions of a different kind, however, in that the regulations attempt to resolve the conflict between two federal statutes-one that it is charged with administering (the MMWA), and one that it is not (the FAA).

Typically, the legal conclusions that agencies draw are fairly limited to each agency's particular area of expertise. ${ }^{182}$ Thus, the MMWA charges the FTC with the responsibility of regulating "informal dispute settlement procedures" ${ }^{1833}$ involving MMWA claims, where the agency's expertise in the area of consumer issues is valuable in establishing these rules. By interpreting the MMWA to prohibit binding arbitration, however, the FTC does not merely decide how best to administer the MMWA, but rather attempts to resolve a conflict between two federal statutes. In deciding this conflict against arbitration,

178 Moses H. Cone Memorial Hospital v Mercury Construction Corp, 460 US 1, 24 (1983).

179 See notes $175-77$.

180 See Sunstein, 67 U Chi L Rev at 340-41 (cited in note 128) (noting that the use of nondelegation canons only infringes on an agency's discretion in a "narrow, targeted way").

181467 US at 842-44.

182 See Alfred C. Aman, Jr. and William T. Mayton, Administrative Law 11-12 (West 1993) (noting the importance of agency expertise in Congress's decision to delegate to an agency).

18315 USC $\$ 2310($ a)(2). 
the FTC has conducted its own mini-McMahon inquiry, an area in which courts clearly have greater expertise than the FTC. Thus, legal issues like this one are better left to judges, whose sole function is to interpret the law. After all, it is the province of the courts to "say what the law is."

\section{CONCLUSION}

The FAA requires the enforcement of all arbitration agreements except where Congress has specifically directed otherwise. Under McMahon, courts consider three factors to determine whether Congress has exempted a particular statute from application of the FAA: the text of the statute, its legislative history, or whether there is an "inherent conflict" between the purposes of the statute and arbitration. ${ }^{185}$ Currently, courts are divided on whether the MMWA meets McMahon's requirements and creates an exception to the FAA. ${ }^{186}$ The primary reason for the conflict between courts is disagreement about whether, and how, courts should consider FTC regulations prohibiting arbitration of MMWA claims.

This Comment proposes that courts applying McMahon should not consider the FTC regulations as evidence of Congress's intent to bar arbitration of MMWA claims because the MMWA does not grant the FTC the power to prohibit arbitration. First, the regulations are not entitled to judicial deference under Chevron because they directly conflict with Congress's intent to uphold arbitration agreements as expressed in the FAA. Second, the MMWA does not change this result. Nothing in the MMWA's text, legislative history, or purposes expressly or implicitly authorizes the FTC's complete ban on binding arbitration. Moreover, interpretation of the MMWA according to presumptions favoring arbitration and continuity in the law only confirms that the MMWA cannot be understood to authorize an exception to the FAA.

Requiring Congress to be explicit when it delegates to an agency the decision whether to prohibit arbitration reduces decision and error costs for both courts and Congress and stimulates political accountability and deliberation. Furthermore, the approach provides a practical resolution to this and future conflicts between the FAA and agency interpretations without undermining an agency's expertise in administering a particular statute.

184 Marbury v Madison, 5 US (1 Cranch) 137, 177 (1803) (noting that it is not only the duty of the courts to apply the law, but also to interpret the law).

185 McMahon, 482 US at 227.

186 See note 13. 